\title{
The EuRo-ARAB Investment Treaty That NEARLy WaS
}

\author{
EILEEN DenZA AND LAUge N. SkOVgaARd PoulSEN*
}

\author{
Forth. International \& Comparative Law Quarterly
}

\begin{abstract}
This article documents how members of the European Economic Community and members of the Arab League negotiated a draft 'mega-regional' investment protection treaty from 1976 to the late 1980s - the first of its kind. The negotiations produced a full draft treaty and came tantalizingly close to completion but ultimately ran into the political sands. Had it been concluded, the Convention would have been the most significant investment protection treaty ever negotiated at the time, and one of the most significant to this day. Negotiations were conducted within the cloak of diplomatic confidentiality, however, so the effort has remained unknown to even specialized scholars and practitioners to this day.
\end{abstract}

Keywords: Euro-Arab Dialogue, international investment law, investment treaties, investment arbitration, legal history, Palestine status, Arab League, exchange controls, freezing, expropriation, European investment policy.

\section{INTRODUCTION}

Mega-regional treaties with investment protection provisions are newcomers to the investment treaty regime. After having failed to conclude multilateral investment protection rules since the early $20^{\text {th }}$ century, ${ }^{1}$ States instead focused on bilateral treaty making from around the $1960 \mathrm{~s}$ onwards. A few regional agreements were concluded in the 1980s and 1990s, like the Arab Investment Agreement, the Energy Charter, and the North American Free Trade Agreement, but in recent years most effort has been directed towards a new type of investment treaty - the

\footnotetext{
* Former FCO Legal Counsellor and Visiting Professor, University College London, eileen.denza@btinternet.com; Associate Professor, University College London, 1.poulsen@ucl.ac.uk. The authors wish to thank Jonathan Bonnitcha, Mona Pinchis, Johnny Veeder QC, and two anonymous reviewers for helpful comments and suggestions. Lauge Poulsen would like to acknowledge support from the Leverhulme Foundation (grant RPG-2018-044). The usual caveats apply.

1 The list of attempts includes: the League of Nations (1928), International Trade Organization (1948), International Law Association (1948), International Chamber of Commerce (1949), the Abs-Shawcross initiative (1959), Harvard Law School (1961), Organisation for Economic Co-Operation and Development (OECD) (1967), UN Centre for Transnational Corporations (1980s), OECD again (1998), and the WTO (early 2000s). There was progress on procedural rules in the 1965 ICSID Convention and in recent years attempts are made in UNCITRAL.
} 
mega-regional. ${ }^{2}$ Major efforts have been undertaken in the Asia-Pacific and across Atlantic; specifically, the Regional Comprehensive Economic Partnership, the failed Transatlantic Trade and Investment Partnership, and the Comprehensive and Progressive Agreement for TransPacific Partnership. Whereas bilateralism and multilateralism were the favoured approaches to investment protection in the $20^{\text {th }}$ century, mega-regional deals have recently offered a 'third way'. The history is well-known, but incomplete.

This article documents how all members of the European Economic Community (EEC) and of the Arab League - 33 in number - negotiated a draft mega-regional investment protection treaty from 1976 to the late 1980 s. It came tantalizingly close to completion but ultimately ran into the political sands. Annex I to this article reproduces the draft Convention in full as it stood in 1985. Its conclusion would have enshrined the standard panoply of substantive investment protection rules found in bilateral investment treaties (BITs) as well as broad and binding consent to international investor-state arbitration among many of the largest capital-exporting States in the world. Ratification by 10 countries on each side would have made it equivalent to 100 BITs. By comparison, less than 200 BITs were then in force worldwide. The Convention would, therefore, have been the most significant investment protection treaty ever negotiated at the time, and one of the most significant to this day. Negotiations were conducted within the cloak of diplomatic confidentiality, so although officials involved did mention the negotiations at the time ${ }^{3}$ details have only emerged through recently opened archives. ${ }^{4}$ The effort has therefore remained unknown to even specialized scholars and practitioners. Textbooks and monographs fail to mention it when outlining the historical origins of the regime, ${ }^{5}$ and even comprehensive works on European investment protection policy ${ }^{6}$ and the history of international investment law ${ }^{7}$ do not cover it.

This article therefore contributes to the emerging 'turn to history' in international investment law, but in different ways from most contributions. First, unlike many contributions that make historical claims about international investment law, it is rooted in primary sources through archival research into the negotiating history as well as the personal recollection of one of the negotiators. ${ }^{8}$ Second, whereas much of the turn to history in investment law has been about the

\footnotetext{
${ }^{2}$ Understood as a treaty with comprehensive investment protection provisions among regions with a major share of world investment.

${ }^{3}$ See; H-M Burkhardt 'Investment Protection Treaties: Recent Trends and Prospects', Aussenwirtschaft 41 (1986), 100, 102; E. Denza and S. Brooks 'Investment Protection Treaties: United Kingdom Experience' 56 ICLQ (1987) 908, at 914. See also Denza in The International Responsibility of the European Union (2013, M Evans and P Koutrakos eds.) ch. 7 at 216-217.

${ }^{4}$ Reference to the negotiations is made in literature on the Euro-Arab dialogue; M Zakariah, 'The Euro-Arab Dialogue 1973-1978: British Reinsurance Policy in the Middle East Conflict,' 20 European Review of History: Revue europẻenne d'histoire (2013), 105.

${ }^{5}$ See e.g.; S Schill, The Multilateralization of International Investment Law (Cambridge University Press, 2007), ch. 2; G Van Harten, Investment Treaty Arbitration and Public Law (Cambridge University Press, 2007), ch 2; M Sornarajah, The International Law on Foreign Investment, $3^{r d}$. ed. ( Cambridge University Press, 2010), ch. 2; C Schreuer and R Dolzer, Principles of International Investment Law (Cambridge University Press, 2012), ch. 1).

${ }^{6}$ A Dimopoulos, EU Foreign Investment Law (Oxford University Press, 2011); R Basedow, The EU in the Global Investment Regime: Commission Entrepreneurship, Incremental Institutional Change and Business Lethargy (Routledge, 2017); R Leal-Arcas, EU Trade Law (Elgar 2019), 22; J Voss, 'The Protection and Promotion of European Private Investment in Developing Countries - An Approach towards a Concept for a European Policy on Foreign Investment: A German Contribution,' 18 Common Market Law Review (1981) (also cited in: W Shan, The Legal Framework of EU-China Investment Relations: A Critical Appraisal (Hart, 2005), 70).

${ }^{7} \mathrm{~K}$ Miles, The Origins of International Investment Law: Empire, Environment and the Safeguarding of Capital (Cambridge University Press, 2013); T Weiler, Interpretation of International Investment Law: Equality, Discrimination and Minimum Standards of Treatment in Historical Context (Martinus Nijhoff, 2013).

${ }^{8}$ See also J Yackee, 'The First Investor-State Arbitration? The Suez Canal Dispute of 1864 and Some Reflections on the Historiography of International Investment Law,' in S Schill, C Tams \& R Hoffman, eds. International
} 
colonial origins of the regime, often from a critical lens, ${ }^{9}$ we describe recent history exploring the drafting of a major investment convention in the 1970s and 1980s. Third, much recent work on the investment regime has focused on historical investor-state disputes, something that often requires archives as investor-state negotiations typically take place in secrecy. ${ }^{10}$ Our article focuses on something more remarkable: a decade-long effort by thirty-three governments to conclude a mega-regional investment treaty, which to this day has remained largely secret.

Finally, our article is not intended to make broader normative claims about the investment treaty regime. Much scholarship seeks to use - and sometimes abuse - history to criticize or justify current investment protection arrangements. ${ }^{11}$ Our aim is instead to supplement the field's collective understanding of the 'near history' of the regime focusing on the objectives and achievements of those involved in the specific economic and political context of the period, which, notably, was before the large-scale arrival of investment treaty arbitration.

We describe the negotiations, as reflected in UK archives. These are particularly relevant as the UK was highly proactive in the negotiations. Together with the Germans, the UK led the European side throughout the negotiations and the 1985 draft closely followed the UK model BIT. The files give insights into intra-European deliberations as well as inter-departmental discussion in Whitehall, highlighting conflicting views on signing an investment protection treaty with major capital-exporting States. Confidential records mean that existing literature has almost never captured intra-governmental deliberations. We focus mainly on the European and specifically UK perspective, but we hope future work will provide complementary insights from other archives particularly from Arab States.

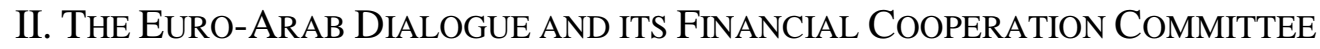

The Euro-Arab Dialogue was formally launched at the European Council in Copenhagen in December 1973 as a result of a French initiative to set up a forum for cooperation between The League of Arab States on the one hand and the EEC and its Member States on the other. From the outset the Arab side saw it as a means of gaining European support for its political objectives - most notably in the context of the Arab-Israeli conflict. For the European side, the overriding objective was to have Arab States take a 'kindlier view' of Europe, or at least 'make

Investment Law and History (Edward Elgar, 2018). For exceptions, see K Vandevelde, The First Bilateral Investment Treaties: U.S. Postwar Friendship, Commerce, and Navigation Treaties (Oxford: Oxford University Press, 2017); M Pinchis-Paulsen, Fair and Equitable Treatment in International Trade and Investment Law: 19181956, PhD dissertation, Kings College London, 2017; T St John, The Rise of Investor-State Arbitration: Politics, Law, and Unintended Consequences (Oxford University Press, 2018); Y Chernykh, 'The gust of wind: The unknown role of Sir Elihu Lauterpacht in the drafting of the Abs-Shawcross Draft Convention,' in S Schill, C Tams \& R Hoffman, eds. International Investment Law and History (Frankfurt: Edward Elgar, 2018); Ira RykLakhman, The Protection of Foreign Investments in Armed Conflicts, PhD dissertation, UCL, 2019; J Hepburn, M Paparinskis, L Poulsen, and M Waibel, 'Investment Law Before Arbitration,' working paper 2019 (which also mentions the Euro-Arab negotiation).

${ }^{9}$ See Miles, supra note 7.

${ }^{10}$ N Maurer, The Empire Trap: The Rise and Fall of U.S. Intervention to Protect American Property Overseas, 1893-2013 (Princeton University Press, 2013); Yackee, supra note 8; J Yackee, 'Investor-State Dispute Settlement at the Dawn of International Investment Law: France, Mauritania, and the Nationalization of the MIFERMA Iron Ore Operations,' 59 American Journal of Legal History (2019) 71.

${ }^{11}$ Not unusual for historical international law scholarship; see R Lesaffer, 'International Law and Its History: The Story of an Unrequited Love,' in M Craven, M Fitzmaurice, and M Vogiatzi, eds. Time, History \& International Law (Martinus Nijhoff 2007). 
the Arabs think twice, if not three times, before taking discriminatory action against us. ${ }^{12}$ The European concern was the 'oil weapon'. Political hopes were high on both sides, but the initiative was vehemently opposed by the US. Although European diplomats saw American interest in the Dialogue as 'slightly hysterical', ${ }^{13}$ fierce American opposition meant that the Dialogue could only succeed if it focused on 'low-politics' initiatives - economic, cultural, and technical cooperation - rather than the sensitive geo-political agenda preferred by Arab League members.

This difference in aspirations meant progress was slow. The European side was frustrated with what they saw as political gesturing by their Arab counterparts. Palestine was the 'only political issue, which they [the Arabs] are interested in discussing', ${ }^{14}$ one official complained, and it caused difficulty when the Arabs insisted that Palestine should participate as no European Member State recognized Palestine as a State. Eventually a procedure was agreed, known as the 'Dublin Compromise', under which the two sides would each sit as a group without disclosing national affiliations. On this basis, specialized Committees were set up for discussion of a wide range of topics under supervision of a General Commission. The agenda was broad - covering trade integration (Arab countries wanted better access to the Common Market), infrastructure and agricultural projects, as well as cultural and scientific exchanges. ${ }^{15}$

The pillar that ultimately made most progress was the Financial Cooperation Committee, chaired initially by the UK Treasury. At a meeting of financial experts in Abu Dhabi in December 1975 it was agreed - largely in consequence of Arab pressure - to set up a SubGroup of the Financial Cooperation Committee with the following terms of reference:

To examine the measures currently in force (including arbitration machinery) in the countries of the League of Arab States and of the European Economic Community for the protection, on a basis of reciprocity, of investments against all forms of non-commercial risks; to consider where, and how, these arrangements might be improved and enlarged on a bilateral and/or multilateral basis, including the possibility of collaboration and joint action between existing or new Arab investment protection institutions; and to make recommendations to the Working Commission on Financial Cooperation of the Euro-Arab Dialogue.

The two sides initially had rather different views on what this meant. 'Measures', 'arrangements', 'collaboration', and 'joint action' on investment protection could cover investment insurance and other financial arrangements, investment laws, informal codes of conduct, and investment protection treaties. The UK Treasury feared that even the specific terms of the sub-group could still result in discussions that would 'ramble very widely' given the Arab tendency to use the Dialogue mainly for a 'political purpose, and efforts to develop technical co-operation [were] frequently foiled by a lack of real concern (and information) on the Arab side.' 16 The Treasury therefore suggested that the European Commission should prepare a background note on existing BITs of European and Arab members together with a summary of legislative and executive investment protection of non-resident investors. At the first coordination meeting among European experts in July 1976, the Treasury focused on BITs of European and Arab parties and whether it would be desirable to negotiate more such treaties,

\footnotetext{
${ }^{12}$ R Miller, 'The Euro-Arab Dialogue and the Limits of European External Intervention in the Middle East, 19741977,' 50 Middle Eastern Studies (2014), 937.

${ }^{13}$ Ibid., 949.

${ }^{14}$ Ibid., 942.

${ }^{15}$ Although the Arab League preferred to focus on 'high politics', it also had a 'shopping list' of what they wanted from economic cooperation, such as unrestricted access to community markets, protections against exchange rate and terms of trade fluctuations, better treatment of their migrant workers, and other trade and insurance initiatives for a deep preferential economic relationship between the regions.

${ }^{16}$ Slater (Treasury) to Kemp (FCO), 1/6/1976; FCO 98/213.
} 
harmonise their terms or 'whether there would be mutual advantage in establishing multilateral arrangements in this field and if so, in what form .' ${ }^{17}$ This last proposal followed a suggestion made by the European Commission in its background note which favoured drawing up a code of good conduct ${ }^{18}$

Due to lack of enthusiasm from the UK Treasury, the chairmanship of the Financial Cooperation Committee and its investment protection sub-group was moved from the Treasury to the UK Foreign and Commonwealth Office (FCO). Internally, the Treasury would have liked the entire Financial Cooperation Committee to be shut down. 'I have a slightly sinking feeling,' one official noted, 'that this enterprise may prove in the end to be rather time-wasting. It is a feature of the Dialogue that the Arabs press many proposals upon the Europeans and from time to time the latter have to concede on some minor issue for the sake of peace; that is how this proposal came about. ${ }^{19}$ The UK sought, however, to show a constructive attitude to the Dialogue as a whole - particularly as it was about to take over the Presidency of the Dialogue. ${ }^{20}$ The FCO had more sympathy for the enterprise and agreed to assume the lead with Eileen Denza, a Legal Counsellor who had led inter-departmental co-ordination of the first UK model BIT, chosen as Co-chairman of the investment protection sub-group before its first European preparatory meeting.

At the first meeting of the sub-group the Arab side was chaired by Jordan's Ambassador to Germany, Denmark, Sweden, Norway, Luxembourg, and the EEC, Nijmeddin Dajani. The Europeans had expected Dajani, an economist by training and the Arab spokesperson for the Dialogue as a whole, to set a broader financial cooperation agenda than 'the technical subject of investment protection. ${ }^{21}$ But it was made clear that the Arab side favoured a binding multilateral agreement on investment protection and sought some form of joint enterprise for the insurance of investment. The European side was receptive to the proposal of a multilateral agreement, which became the focus of discussions. All members agreed that BITs 'had proved useful in practice, and in particular that they had helped to improve the investment climate and might have helped to increase the flow of investment between different countries', but that a multilateral agreement could 'supplement and fill the gaps in the bilateral agreements. ${ }^{22}$ It was further agreed to pursue a wide definition of the term investment, to include portfolio investment, short-term investment and monetary claims as in the 1975 UK Egypt BIT. ${ }^{23}$ Consideration was also given to measures relating to investment cooperation - which today would fall under the 'investment facilitation' - such as freer exchange of information about investment opportunities and cooperation among investment insurance agencies. ${ }^{24}$ But from then the main focus was the proposed Convention. ${ }^{25}$

\footnotetext{
${ }^{17}$ Slater (Treasury) to Kelley (FCO), 18.6.1965; T 383/98.

${ }^{18}$ Commission doc. 1/95/76; minute by Sinclair (FCO) to Gardiner (FCO Legal Advisers), 11.6.1976; FCO 98213.

${ }^{19}$ Slater (Treasury), to Kemp (FCO), 4.2.1976; FCO 98-213.

${ }^{20}$ Slater (Treasury) to Sir D Mitchell (Treasury), 19.1.1976; T 383-98; Euro Arab Dialogue: Financial Cooperation Working Group; Sinclair (FCO) to Maud (FCO), 8.6.1976; FCO 98/213;

${ }^{21}$ Sinclair (FCO) to Gore-Booth (UKREP), 8.7.1976; FCO 98/214.

${ }^{22}$ Euro-Arab Dialogue - First Report of the Sub-Group on Investment Protection, FCO 98-215.

${ }^{23}$ Ibid.

${ }^{24}$ Ibid. The UK was constrained as promotion of outward investment was politically sensitive and Labour and the unions were concerned about inward investment displacing UK jobs and investment. Wasilewski (Department of Industry) to Thomas (FCO), 5.10.1976, 1976. This was also a concern in the early US investment treaty programme, which was why the State Department could not justify the agreements by promoting US outflow of investment; Vandevelde.

${ }^{25}$ Faber (FCO) to Maud (FCO), 13.12.1976; FCO 98-216.
} 
It became clear, however, that while the Arabs wanted 'the negotiation of some "multilateral agreement" between the EEC and the Arab League on investment protection, ${ }^{26}$ they had a major interest in protection against monetary risks such as exchange rate fluctuations. ${ }^{27}$ Arab representatives from the General Committee noted in private that protection against monetary risks was their most important objective, whereas the European focus on non-monetary risks was a 'secondary' consideration. While accepting that the European proposal could induce further investment into the Arab members, the Arabs also wanted the Europeans to acknowledge that protection against monetary risks would result in further Arab investments in Europe. ${ }^{28}$ The Arabs did not follow up with specific proposals, however, such as a ban on devaluations of currencies in which they held assets (e.g. pounds) and the Europeans refused to even consider incorporating protection against monetary risks in such a convention. They argued it was beyond the competence of EEC members to discuss and sought guidance from the Financial Co-operation group. ${ }^{29}$ As no further specific proposals were made at that time by the Arabs on this issue, the main focus from then on was a mega-regional investment treaty similar to existing BITs.

This was a major initiative, sharply different from the investment negotiations reflected in agreements in force. First, the move away from bilateral negotiations meant that European and Arab States had to coordinate positions among themselves, thus highlighting national differences in approach. Secondly, there was a real balance of economic interest between the two sides. On the Arab side there were some developing States, and initially the Arab group considered it 'unreasonable to expect reciprocity of treatment in the investment field, in view of disparities of economic development; [arguing that] it is unrealistic to expect from them the same undertakings in regard to European investment as they seek from us. ${ }^{30}$ But there were also oil-rich States, such as Saudi Arabia, which held extensive investments of many kinds property, shareholdings, loans and bonds - in Europe. These States were highly conscious of the risks of political interference by governments as well as currency fluctuations and were represented by experienced financial negotiators. Negotiations with the Arab League therefore were bound to be different from traditional 'North-South' negotiations as both sides sought 'strong' investment protection. European States would have to give closer consideration to possible liabilities arising from such an agreement, whereas most of their existing BITs were with States with negligible outward investment flows. The UK, in particular, had strong reasons to consider the implications of the treaty as most Arab investment in Europe was in the UK so-called 'petro-dollars' - while the UK had no comparable investment in Arab States. ${ }^{31}$ An additional challenge was that much Arab investment came from governments as well as government-controlled agencies - something not traditionally covered by European BITs.

An initial complication was to determine who the parties to any treaty would be. The Arabs suggested an agreement between the Arab League and the EEC. The European Commission claimed competence to become a Party to any agreement on the basis of Article 113 of the EC Treaty (the provision which from the outset had given the EEC competence for its common commercial policy). Article 113 however implied an exclusive competence for the EEC (thereby eliminating participation by Member States) and was strongly resisted in this as in

\footnotetext{
${ }^{26}$ F Slate to Kemp, 4.2.1976; FCO 98-213.

27 Thomas (FCO) to Maud (FCO), 21.12.1976; FCO 98/216.

${ }^{28}$ Faber (FCO) to Maud (FCO), 13.12.1976; FCO 98-216.

${ }^{29}$ First Report of the Sub-Group on Investment Protection, FCO 98-215; Thomas (FCO) to Winkler (Treasury), 22.10.1976; FCO 98-215.

${ }^{30}$ Working Group on Financial Co-operation: assessment of UK interests and objectives; Note by the Treasury, 24.01.1976; FCO 98-213.

${ }^{31}$ Perfect (Treasury) to Denza (FCO), 2.7.1982; T 450/72.
} 
many other contexts where the Commission sought to enlarge the scope of Article 113. The idea of joint EEC investment protection agreements were being discussed at the time, for instance in the context of mining investments, and some European States - like Italy and Belgium - thought 'the conclusion of such agreements at a Community level would be more effective than national arrangements. ${ }^{32}$ By contrast, France, Germany, and the UK were strongly opposed to allowing their experience to be replaced by Commission negotiators who had at that time no direct experience in the field, and so the idea of EEC exclusive competence over a Euro-Arab investment treaty was firmly rejected. As regards the Arab League, Arab lawyers conceded that the League had no internal or external competence on investment protection.

If any convention was to be concluded among States, this raised the separate problem of how Palestine could become a Party. ${ }^{33}$ To resolve this, Denza suggested, and explored in London, the idea that instruments of signature and ratification might be deposited in either of two capitals - Brussels, where the EEC Member States would sign, or Cairo, then the headquarters of the Arab League, where the Arab States together with Palestine would sign. This followed the precedent first used in 1963 for the Partial Test Ban Treaty - where instruments might be deposited in London, Moscow or Washington so as to enable East Germany, North Vietnam and other entities not then generally recognized as States to become Parties. Palestine was a Member of the Arab League, so that it was believed that deposit of an instrument by it in Cairo would not be challenged there on grounds of non-recognition. ${ }^{34}$ This procedure was not initially rejected outright (though it was challenged at a later date).

At this point when European experts began to pool their experiences of negotiating BITs, Germany - which concluded its first BIT in 1959 with Pakistan - was party to the largest number, with France and The Netherlands some way behind. The UK entered the field later mainly in response to challenges from developing countries such as the General Assembly Declaration and Programme of Action on the Establishment of a New International Economic Order ${ }^{35}$ and the Charter of Economic Rights and Duties. ${ }^{36}$ There was however a shared approach to the basic issues and there had already been a degree of cross-fertilization and common sources $^{37}$, so it was not difficult to agree on the outlines of a European model BIT to present to the Arab side. The European co-ordination meetings were also helpful in providing information and sharing experiences.

\section{THE NEGOTIATIONS}

Negotiations alternated between Brussels and the Arab League Headquarters - initially in Cairo. The European Commission was represented throughout and gave administrative support but was otherwise given a subsidiary position by the European Member States, who sent a first text on investment protection principles in 1977. The Arabs sent their response in August the

\footnotetext{
${ }^{32}$ Sinclair (FCO) to Faber (FCO), 16.6.1976; FCO 98-213.

${ }^{33}$ Denza (FCO) to Shepherd (FCO), 27.10.1976; FCO 98/216.

${ }^{34}$ Ibid.

${ }^{35}$ GA Res.3201 and 3202 (SVI) adopted 1 May 1974.

${ }^{36}$ GA Res. 3281 adopted 12 December 1974 by roll call vote with several European States voting against: Chatterjee, 'The Charter of Economic Rights and Duties of States' 60 ICLQ (1987) 669.

${ }^{37}$ In particular the OECD Draft Convention on the Elimination of Foreign Property, OECD Publication No.15637/ Dec.1962. The Convention was never opened for signature but had considerable influence at the time.
} 
following year, and a number of potential stumbling blocks were resolved a few months later at the November 1978 Cairo meeting. ${ }^{38}$ In particular, the document was to include:

- A definition of investment that was 'broadened to the maximum extent'.

- Coverage of all investment, existing and new, though each State should retain the right to regulate the admission of new investment.

- A general clause according to which each Party 'would do its best both to promote and to protect other Parties' investments; consistently with national economic policy'.

- National and most-favoured-nation treatment, though with exceptions (including concessions granted in the framework of a customs/economic/monetary union or free trade zone; portfolio investment; taxation).

- The right to review of the legality of any taking and of the valuation, by an independent judicial or administrative authority in the host country. Compensation should reflect the market value of an investment, assessed immediately before the expropriation or public knowledge of it, be paid without delay and be fully transferable.

- Free transfer of payments and all income from an investment with exceptions for exceptional balance of payments difficulties and, possibly, sudden withdrawal of all investments.

- Provision on subrogation.

- Binding dispute resolution. Inter-state disputes should be referred to an arbitral tribunal and investorstate disputes 'should also be referred to some form of international arbitration'.

Moreover, the provisions 'should be considered in principle as minimum treatment', and the more favourable provision for the investor should prevail in case of conflict with other bilateral agreements. Issues for future discussions included the relationship between national treatment and requirement for payment of compensation in the event of requisition or destruction not caused by the necessity of the situation. Importantly, there was also no agreement on whether reference to ICSID and its additional facility rules should be compulsory, and there was also to be further discussion of a possible non-judicial dispute settlement mechanism in the form of a Committee. But the skeleton of a mega-regional Euro-Arab investment treaty was emerging, and this only a few years after the Declaration for the Establishment of a New International Economic Order.

On this basis, the European side proceeded to formulate a draft convention 'drawn up on the same lines as the usual type of bilateral investment promotion and protection agreement. ${ }^{39}$ Although European States had a shared approach and common sources, this was 'an exhausting', and 'at times acrimonious', exercise for the EEC members. ${ }^{40}$ Nevertheless, by early 1979, a draft was forwarded to the Arabs. ${ }^{41}$

Political events then put discussions to a halt as all Dialogue activities were suspended following Egypt's expulsion from the Arab League in the wake of the Camp David Agreement. Later that year, the League moved its headquarters to Tunis and sought to renew the Dialogue. Europeans accepted, but the Arab side wanted to shift the focus back to broader geo-political political questions - including reviving demands for recognition of the PLO. ${ }^{42}$ The Europeans rejected this, so although the Dialogue formally restarted, limited progress made one Arab delegate call it 'nothing but a hoax' that was 'at a complete standstill'. ${ }^{43}$ For the Europeans, on

\footnotetext{
${ }^{38}$ FCO 69-647.

${ }^{39}$ European Financial Cooperation Working Group (FCWG), note by Gowland (FCO), 30.03.1981.

40 Evans (FCO) to Balfour (Bank of England), 27.2.1981; FCO 69-643; Euro-Arab Dialogue: Investment Protection; Gowlland (FCO) to Braithwaite (FCO) and Lord Bridges (FCO); 30.9.1981; FCO 69/648.

${ }^{41}$ Denza (FCO) to Ohlmann (European Commission), 22.03.1979; FCO 69-643; Watson (FCO) to Abdulla elKuwaiz (Arab League), 19.5.1981; FCO 69-645.

${ }^{42}$ Financial Cooperation Working Group, note by Gowlland (FCO), 30.10.1981; FCO 69-644.

${ }^{43}$ Miller, ibid., 954.
} 
the other hand, 'the burden of failure to make any progress lay with the Arabs' ${ }^{44}$ Either way, the broader objective of using the Dialogue as a major political and economic integration effort had by 1981 lost all momentum. The proposed trade agreement had stalled, ${ }^{45}$ and few expected any tangible successes. The major exception was the investment treaty.

The Financial Cooperation Committee, chaired by Germany, took over the Investment Protection Sub-Group. Dr Hans-Martin Burkhardt, an experienced investment protection negotiator from the Department of Economic Affairs in Bonn became European Co-Chairman, while Eileen Denza for the UK became European Rapporteur and worked closely with Dr Burkhardt. In terms of forming a collective position, however, the Arab League States were actually somewhat ahead of the Europeans. More than half of all South-South BITs from 1964 to 1986 were among Arab League members and in 1980, during the Eleventh Arab Summit Conference in Amman, agreement was reached on the Unified Agreement for the Investment of Arab Capital in Arab States, which entered into force on 7 September $1981 .{ }^{46}$ The Arab position in the Euro-Arab talks was closely based on this agreement, which gave extensive protection to government as well as to private investment as well as a guarantee that investment might be transferred out of a host country at any time. As in European BITs there were tight limits on expropriation and provision for compensation for the investor at fair market value. In 1985, the Arab League Agreement was further complemented by establishment of the Arab Investment Court.

There was no equivalent intra-EEC treaty, and the Europeans still had to address a number of critical questions. The position of the European States on Article 113 as the base for EEC participation had not changed. ${ }^{47}$ The Europeans were however content to allow the EEC to become a Party to any agreement along with its Member States and a different legal base for a mixed agreement was identified - the financial stake held by the European Investment Bank in several developing Arab States

Secondly, and much more difficult, was the UK demand to follow two aspects of its then model BIT. Most contentious was the transfer clause. The Treasury in particular, but also the Bank of England had 'always attached the greatest important [sic] to maintaining our freedom to introduce exchange controls' ${ }^{48}$ They were scarred by the experience of the so-called 'Kuwait gap', where tens of millions of dollars were lost during the 1950s through evasion of exchange controls $^{49}$ and strongly resisted the provision favoured by Germany and others entitling

\footnotetext{
44 Summary of meeting at The Hague, 21 and 22 May 1981, of the Euro-Arab Dialogue Ad Hoc Preparatory Group, Note by FCO's Near East and North Africa Department (NENAD), 8.6.1981; FCO 69-645.

${ }^{45}$ Rowlands (DOT) to Lambert (FCO), 28.5.1981, FCO 69-645.

${ }^{46}$ League of Arab States 1982 Economic Documents No. 3. The Agreement was ultimately ratified by all Members of the Arab League except Algeria and the Comoros. In 1981, within the framework of the Islamic Conference, there was also concluded an Agreement on Promotion, Protection of Investments amongst the Arab States.

${ }^{47}$ Denza (FCO) to Gowlland (FCO), 30.3.1981; FCO 69-644. See also European Financial Cooperation Working Group (FCWG), note by Gowlland (FCO), 30.03.1981; Denza (FCO) to Powell (UKREP), 31.3.1981; Saunders (Treasury Solicitor's Department) to Hodges (Treasury), 8.4.1981; FCO 69-644; FCO 69-644; note by Gowlland (FCO), 30.10.1981; FCO 69-644; European Commission, Participation of the Community as co-contracting party to the draft Euro-Arab Convention for the Reciprocal Promotion and Protection of Investments,' Commission working document, $\operatorname{Sec}(81) 689,4.5 .1981$.

${ }^{48}$ Lavelle (Treasury) to Evans (FCO), 16.10.1981; FCO 69/950.

${ }^{49}$ Gowlland (FCO) to McLean (FCO) and Evans (FCO), 23.11.1981; FCO 69-650. The UK maintained that some other European States - Greece in particular - had laws under which this limitation would be needed, but in spite of energetic lobbying failed to gain support; Letter of 13 January 1982 from Mark Gowlland, Trade Relations and Exports Department (TRED), FCO, to Chancery, Athens; Letter of 20 January 1982 to Mark Gowlland from Peter Davies, British Embassy, The Hague. Within the UK, the DOT differed from the Treasury and Bank of England suggesting that the UK should follow other European (and Arab) governments to safeguard funds UK investments
} 
investors to free transfer to any other State of their investment and returns from it. Other European States saw no problem in permitting exchange controls to be imposed in exceptional financial or economic circumstances, but resisted proposals to limit the free transfer guarantee to the country of residence of the investor. Imposing exchange control restrictions on a basis of residence was seen as particularly important in the context of this Agreement given the inclusion of Saudi Arabia, Kuwait, and Qatar. The trouble for the UK, however, was 'that none of our EC partners like our formula. ${ }^{50}$ This became the largest obstacle to a joint European position, as the UK position was seen as 'far too weak' by European partners who expressed concern about the precedent it would set for future BITs ${ }^{51}$ Germany was particularly fierce in its opposition. UK negotiators noted that the 'champion of a right for the investor to free transfer without limit is Germany. ${ }^{52}$ Dr Burkhardt was supported by most European Member States in making sure the draft followed the German, rather than UK, model BIT on this. ${ }^{53}$ Consistently with the Unified Arab Agreement mentioned above, the Arab side sought to entitle investors to free transfer of their capital and income from it without any restriction as to destination. This would secure the Arabs' considerable portfolio investment in Europe ('petrodollars'). ${ }^{54}$ But the UK persisted, and in September 1981 the Europeans told the Arabs that this intra-European discussion remained unresolved. ${ }^{55}$

Another sticking point was that UK law had a few cases of nationality-based tax discrimination, and therefore sought to exclude taxation from non-discrimination provisions. UK BITs excluded taxation entirely - on the basis that it should be dealt with in double taxation agreements negotiated between experts in national tax laws. The Arabs should have agreed. Nationality-based tax discrimination was integral to the Saudi and Kuwaiti tax systems, for instance, as foreigners were subject to income tax whereas nationals were subject to (much lower) zakat. ${ }^{56}$ But to the surprise of London, the Arab side suggested that most-favoured nation and national treatment provisions should apply to taxation, something UK officials expected must be a mistake as it would 'seriously inhibit the operation of their income tax laws'. ${ }^{57}$ Other European States, however, wanted to keep tax exceptions to national treatment to a minimum.

One UK official explained the situation thus:

... it has not been and is not simply a question of persuading the other side - the Arabs - to accept wording we in Whitehall want. We have had first to persuade our European partners to agree the wording with us. This process has been something of an educational shock. The floors of the Conference rooms where the Euro-group has met have been littered with the debris of 'draft formulae' and 'alternative drafts' - mostly from our various EC partners - which met with little or no support. ${ }^{58}$

These two issues notwithstanding, the Europeans could present a joint draft to the Arab side by 1981 with agreed text on almost all provisions. This also served a broader political purpose

\footnotetext{
in the region (the department was seeking to promote investment into Saudi Arabia); Smith (DOT) to Lawelle (Treasury), 13.10.1981; FCO 69/650.

${ }^{50}$ Gowlland (FCO) to McLean (FCO), 4.10.1981; FCO 69/649.

${ }^{51}$ Evans (FCO) to Balfour (Treasury), 5.11.1981; FCO 69-649.

${ }^{52}$ Ibid.

${ }^{53}$ Denza (FCO) to Walker (Treasury), 28.11.1985; FCO 98-2270.

${ }^{54}$ Watson (FCO) to Lord Bridges (FCO), 15.7.1981; FCO 69-646.

${ }^{55}$ Report of the Financial Cooperation Committee, 25.9.1981; FCO 69-648.

${ }^{56}$ Letter from Edwards (Inland Revenue) to Gowlland (FCO), 17.8.1981; FCO 69-647.

${ }^{57}$ Ibid.

${ }^{58}$ Gowland (FCO) to Yarnell (DOI), 4.12.1981; T 450-71.
} 
as the draft was explicitly used 'as evidence of European interest in progress' for the Dialogue as a whole. ${ }^{59}$

Europeans expected that the Iranian revolution had made clear to the Arabs 'that investment protection was a real problem for them too' ${ }^{60}$ But internally they accepted that the $1981 \mathrm{draft}$ 'would probably benefit the European side more than the Arabs'. ${ }^{61}$ Although precision on stocks controlled by Europeans in the Arab region was not available, minority shareholding in a wide range of industries across the region was considerable and the expectation was that the protection of minority shareholdings would be considered helpful by 'particularly large companies like Shell and RTZ', and the agreement would be 'much more of a sacrifice of their [Arab members] "national sovereignty" than for the European side, because the gap between how some of them treat investors and the provisions of the Convention is much wider. ${ }^{\prime 62}$ Yet, at the September 1981 meeting, the Arab side made clear that they also wanted the treaty 'finalized as soon as possible' ${ }^{63}$ and with as little 'fuss as possible'. The Saudis even said they would use aid flows to other Arab members 'as a lever to exert pressure on these to sign and ratify promptly. ${ }^{64}$ This referred to Libya and Syria, described as using the technical negotiations 'only with the object of sabotage. ${ }^{65}$

Important problems however remained. First, a large proportion of Arab investment in Europe - bonds, loans, real property and shareholdings - was held by Arab States or by government agencies, and the Arab side sought to include this investment in the guarantees to be provided. The controversy over foreign sovereign investment is not only a recent phenomenon. European public opinion had been alarmed over construction by Kuwait of a high-rise block in the Défense area of Paris and Arab stakes in firms like Fiat and Krupps. ${ }^{66}$ European BITs were typically silent on whether they covered only investment by private individuals or bodies - and some of the provisions giving rights to private investors were not appropriate for governmentowned investment. An updated draft sent to the Arab side in March 1982 included investment by government agencies separate from the State itself, but the Europeans argued that to extend the Agreement to sovereign State Parties would raise difficulties due to the special status of States, and in particular the rules on restricted state immunity already applied by European States. These rules - given effect in the 1972 European Convention on State Immunity ${ }^{67}$ to which several EC States were Parties - appeared to surprise Arab States. Privately, however, the European side accepted that if no provision was made for sovereign state investment, there would be a significant imbalance in any agreement. ${ }^{68}$ The German Chairman Dr Burkhardt admitted that the Europeans' line of defense on this point was 'really little more than a smoke

\footnotetext{
59 The Treasury saw investment protection as 'one of the few areas where some positive progress seems possible in the Euro-Arab Dialogue - even though there seems to be some doubt in Whitehall whether such a Convention will ever get signed.'; Hodges (Treasury) to Wheldon (Treasury Solicitor's Department), 31.3.1981; FCO 69-644.

${ }^{60}$ Watson (FCO) to Graham (FCO), 24.6.1981; FCO 69-646.

${ }^{61}$ Gowlland (FCO) to Moberly (FCO), 22.6.1981; FCO 69-645.

${ }^{62}$ Gowlland (FCO) to Moberly (FCO) and Graham (FCO), 25.6.1981; FCO 69-645.

${ }^{63}$ European Commission, 'Draft Final Communique of the Euro-Arab Dialogue Ministerial Meeting,' 17.6.1981; FCO 69-645.

${ }^{64}$ Gowlland (FCO) to Braithwaite (FCO) and Lord Bridges (FCO); 30.9.1981; FCO 69/648; Euro-Arab Investment Agreement; Kay (Inland Revenue) to Loten (FCO), 16.11.1981; T 450/72.

${ }^{65}$ Denza (FCO) to Egerton (FCO), 5.2.1985; FCO 98-2270. A few years later, the Saudi co-chairman suggested that if 'saboteur' Arab League members continued resistance, the Convention could be signed with the Gulf Cooperation Council; Denza (FCO) to Makepeace (NENAD), 1985; FCO 98-2270.

66 European Commission, 'The European Community and the Arab World,' Information: Cooperation development 169/78 (1978), 17.

6711 International Legal Materials (1972) 470.

${ }^{68}$ Denza (FCO) to Yarnell (DOI), 23.6.1982; T 450/72; Note of Working Group Meeting on 25 May, 28.5.1982; $\mathrm{T} 450 / 72$.
} 
screen,' and the UK noted that 'the technical problems are not in fact insuperable given a genuine will on both sides. ${ }^{69}$ To help the Arabs, a preliminary suggestion was made to consider a declaration on favourable treatment and non-discrimination against government investment.

Secondly, the Arabs sought to ban freezing of an investor's assets for political reasons. European members resisted express provision to this effect. Should the Arab countries resort to the 'oil weapon', for instance, Europeans wanted to be able to freeze Arab assets in selfdefence. ${ }^{70}$ The UK was again particularly concerned, as it had recent experience of freezing in the context of Iran and of Argentina at the time of the latter's invasion of the Falkland Islands. ${ }^{71}$ But the Europeans had some sympathy for the Arab proposal, and at the 1982 joint meeting it was accepted that this was a highly political issue which could only be resolved in the context of overall agreement on a Convention.

The Arabs made other suggestions which were seen as less important. First, in the 1978 meeting, initial discussions about ICSID - to which not all members of the Arab League were party - had shown that the Arabs preferred an entirely voluntary provision on investor-state arbitration. ${ }^{72}$ The Arabs later accepted binding arbitration, but it is notable that there was not much discussion of the possible implications of investor-state arbitration in the records. One reason could be that investor-state arbitration was available in the 1980 investment treaty among members of the Organization of the Islamic Cooperation (OIC) - with considerable overlap in membership with the Arab League. ${ }^{73}$ In 1982 the Arabs proposed a requirement for exhaustion of local remedies before investors could access international arbitration, claiming this better reflected customary international law, but the proposal was rejected by Europeans on the grounds that practice was 'now moving in the direction of providing swift and effective forms of international arbitration. ${ }^{74}$ The Arabs conceded the point, perhaps because the OIC treaty had no exhaustion requirement. They also continued to resist excluding taxation, to the frustration of the UK. ${ }^{75}$ Yet, by November 1982 taxation experts had finally convinced other Europeans - even Germany - of the UK position that taxation should be excluded from the nondiscrimination provisions. ${ }^{76}$ The Arabs conceded this as well, acknowledging that their proposal went against tax laws of several Arab League members.

On the European side, more than 50 proposals had to be discussed among the European partners in 1982, mostly from the French, Belgians, Dutch, and Germans. ${ }^{77}$ Two French concerns in particular became the subject of discussion. A forthcoming French Nationalisation Law criticized by the Conseil d'Etat as not being justified by 'public necessity' - made the French question provisions on review of legality of expropriation and of valuation. The French also sought to exclude earlier disputes from the Convention as it had a list of long-standing and

\footnotetext{
${ }^{69}$ Denza (FCO) to Yarnell (DOI), 23.6.1982; T 450/72.

${ }^{70}$ Gowland (FCO) to Moberly (FCO) and Graham (FCO), 29.6.1981; FCO 69-646.

${ }^{71}$ Extensive discussions took place within the UK on this. The FCO sought to reassure the Treasury and the Bank of England that freezing for political reasons would be justified to give effect to a Security Council Resolution, as a measure of self-defense or in reliance on international rules on retaliation - and that these circumstances would override specific guarantee against freezing in the Agreement; Denza (FCO) to Norman (Bank of England), 7.12.1982; Norman (Bank of England) to Denza (FCO), 13.12. 1982.

${ }^{72}$ Euro-Arab Dialogue: Coreu note, CPE/BIL/ETR 501, 1981; T450/72.

${ }^{73}$ Later confirmed by the Al-Warraq v. Indonesia tribunal.

${ }^{74}$ Report of the Financial Co-Operation Committee, 25.11.1982.

${ }^{75}$ Denza (FCO) to Yarnell (DOI), 13.6.1982.

${ }^{76}$ The Belgians and French argued that even if the Convention should prohibit discriminatory tax treatment, they doubted whether it would work 'in practice'. Kay (Inland Revenue) to Denza (FCO), 19.10.1982; T 450/72.

${ }^{77}$ Gowlland (FCO) to Yarnell (Dept of Industry), 25.1.1982.
} 
unsettled disputes with Morocco, Tunisia, and Algeria. ${ }^{78}$ The former point was not accepted by the other Europeans, but France prevailed on the second point and the Arabs accepted this in November 1982.

Negotiators now saw the Convention as 'ripe to be pushed to conclusion'79, and in December the following year there was a high-level meeting in Athens of the General Committee of the Dialogue to take stock of both the political and economic aspects of the work. The draft Convention featured strongly among the successes achieved by the economic side of the Dialogue. In the absence of substantial movement on the political aspects of the Dialogue, however, the Athens meeting barely addressed the outstanding issues.

By 1985, differences had been reduced to a few which could be resolved only by compromise at the political level. The Arabs still insisted that the Convention should ban freezing of investment unless taken in application of judicial measures (Article 5(3) in $1985 \mathrm{draft}$ in Annex). They did not accept a European proposal for an Article permitting reservations to the Convention - even though limited to the transfer clause (Article 13 of $1985 \mathrm{draft}$ ). ${ }^{80}$ The UK Treasury insisted that if a reservation to the transfer clause was not accepted, they would rather abandon the agreement as offering 'little to the UK' ${ }^{81}$ The Treasury even inquired with the FCO what would happen should the UK sign the Convention but ignore an adverse international arbitration award ('FCO please advise on consequences of ignoring a decision against us here...'). ${ }^{82}$

As to potential Parties, the Europeans now strongly favoured a mixed agreement to which the European Community would become a Party along with its Member States on the basis of its holding investments in Arab States through the European Development Fund. The Arab side sought reciprocity on this - but the Europeans continued to resist the possibility of the Arab League becoming a Party since it had neither treaty-making capacity nor any basis of external competence. They were, however, open to participation by Arab bodies with appropriate legal capacity, such as the Arab Monetary Fund (square-bracketed proposal in Article 14(5) of the 1985 draft). This draft opened participation to 'States Members of the Arab League' and required instruments to be deposited both with the EEC Council and the headquarters of the Arab League - so excluding Palestine. Finally, and critically, the Arabs accepted inclusion of natural resources, and the Europeans allowed express inclusion of government investment (together with clarification that international law rules on state immunity should apply Articles 1(d)(iii) and 2 of the 1985 draft).

The Convention was now close to agreement. And although the broader Dialogue stalled during the 1980s, it was in retrospect 1985 where the negotiations came closest to success. The year after, new EEC members Spain and Portugal would join any talks, which would probably cause delays, ${ }^{83}$ and the technical work had gone as far as was possible without a political push

\footnotetext{
${ }^{78}$ Gowlland (FCO) to Braithwaite (FCO) and Lord Bridges (FCO); 30.9.1981; FCO 69/648; undated letter from Denza (FCO) to Gowlland (FCO); FCO 69/648; Yarnell (Department of Industry) to Gowlland (FCO), 21.6.1982; $\mathrm{T} 450 / 72$.

${ }^{79}$ Denza (FCO) to Gowlland 7.12.1982; FCO 69-960.

${ }^{80}$ Article 7 of the 1985 draft - would have allowed free transfer of earnings but permitted host States to phase over several years repatriation of capital invested;

${ }^{81}$ Draft letter from Walker (Treasury) to Kelly (Private Secretary to Chancellor Nigel Lawson), 13.9.1985; FCO 98-2270.

${ }^{82}$ Ibid. The FCO responded that they would not accept 'a submission which proposed even as an option to Ministers that they should become parties to a Convention which they were not prepared to observe in certain foreseeable circumstances.'; Denza (FCO) to Walker (Treasury), 28.10.1985; FCO 98-2270.

${ }^{83}$ Denza (FCO) to King (FCO), 26.7.1985; FCO 98-2270.
} 
towards conclusion. A 'denial of benefits clause' had been drafted to exclude investments controlled by nationals of third states with which the denying State had not entered into diplomatic relations (Arab members were concerned mainly with possible control by Israeli nationals) ${ }^{84}$ The only remaining sticking points were the Arab concerns on freezing of assets and reservations to the transfer clause, ${ }^{85}$ both of which would require discussion at political level. In seeking guidance from Near East and North Africa Department and from European Communities Department (External), Eileen Denza set out the position thus:

\begin{abstract}
We have come to accept that it would not be politically possible to finalize and open for signature this draft Convention except in the context of a General Commission or a Ministerial meeting. ... it is difficult to see the very simple questions of freezing and reservations being finally settled before Ministers or senior officials are about to sign a text. Given that Chairmen and Rapporteurs normally attend a General Commission meeting, I would think it quite possible that we could resolve the outstanding points and sign a text in the margins of a further meeting of the General Commission. ${ }^{86}$
\end{abstract}

The Arab States, under their new Co-chairman Dr. Osama Faquih, Saudi Arabian Deputy Minister for International Economic Cooperation, also wanted the agreement concluded but said this required political movement from the Europeans. During 1986, however, unrelated developments cooled the political climate between Europe and the Arab States. In April the UK and some other EC States offered support for the US bombing of Tripoli and Benghazi claimed to be an exercise in self-defence following Libya's terrorist activities and in particular the bombing of the La Belle Discotheque in Berlin which caused deaths and injuries to US servicemen. Several months later the UK broke diplomatic relations with Syria - making public its evidence that Syrian Embassy diplomats in London were involved in an attempt to sabotage an El Al aircraft by smuggling a bomb on board carried by an unwitting Irish passenger who believed she was travelling from Heathrow to Israel to join her Syrian boy-friend (later convicted and jailed for his part in the conspiracy). Libya and Syria were of course the two States earlier identified as having no genuine interest in the promotion or protection of EuroArab investment. Although both the European and the Arab States were divided over the issues involved, there was no overall political warmth pushing the Euro-Arab Dialogue towards conclusion of a major inter-regional deal.

In December 1989, the French Presidency made a determined effort to relaunch the Dialogue by convening a Ministerial Conference in Paris, followed by a meeting of the General Commission in June 1990. Any hope of progress on investment protection, however, was again overtaken by political events - in particular the invasion of Kuwait by Iraq and the subsequent military action to liberate Kuwait. The Euro-Arab Dialogue and the draft Investment Protection Convention ran into the sands and over time were largely forgotten.

\title{
IV. DISCUSSION
}

Looking back over the Euro-Arab investment negotiations, a number of familiar themes stand out. First, and critically, the negotiations were explicitly seen as setting a precedent for future investment protection rules and, possibly, a world-wide investment treaty. From the European side, the negotiations were seen less as a benefit for specific European firms, and more as part of a broader effort to strengthen customary international law standards against the New International Economic Order: 'If we can get the Arabs on board, then, in terms of economic

\footnotetext{
${ }^{84}$ Denza (FCO) to Burkhardt (German Ministry of Economics), 21.11.1985; FCO 98-2270.

${ }^{85}$ Richmond (ECD) to Makepeace and Egerton (FCO), 6.12.1985; FCO 98-2270.

${ }^{86}$ Minute of 17 December 1985 to Makepeace, NENAD, copied to TRED and ECD (E).
} 
weight, a major part of the developing world will have endorsed European views on the promotion and protection of investment. ${ }^{, 87}$ The Europeans were particularly gratified by Arab acceptance of compensation at market value, which could set an important precedent in broader international debates. ${ }^{88}$ UK lawyers praised the text as showing "classical rules on compensation and non-discriminatory treatment being accepted by a wide cross-section of developed and developing States. ${ }^{99}$ Broader standard-setting is a core argument in favour of mega-regional investment treaties in the $21^{\text {st }}$ century, but it is not a new argument.

Secondly, like OECD's Multilateral Investment Agreement (MAI) in the following decade, this was an effort led mainly by mid-level officials in capital-exporting States with similar views about the principles and rules that should govern foreign investment protection. The technical obstacles were largely overcome - if sometimes helped by unrelated developments. But as with the MAI, the exercise ultimately lacked the necessary support at senior political levels to push the agreement to a conclusion. ${ }^{90}$ Negotiators believed that the talks were not so different from bilateral BITs which, once a text was completed, could await some high-level visit enabling Ministers to take the credit. But negotiations among capital-exporting states are more difficult, as has become clear in recent years, and once it became clear that a determined initiative at the political level would be a prerequisite for completion, the project stalled - as with the MAI (although there the controversy was caused by the investment rules themselves).

Third, the fact that the negotiations faltered so close to the finish did not lead to objections from the European or Arab business community. There was never much business interest in the negotiations in the first place - apart from an early proposal from UNICE to sit in on negotiations. This is similar to BIT negotiations at the time. ${ }^{91}$ Although UK investors held most assets in the Arab region, the UK files include hardly any reference to input, or even interest from European firms in the Convention, ${ }^{92}$ and as with the failed MAI the business cavalry never arrived to save the day for the Euro-Arab Investment Convention. ${ }^{93}$

Finally, it is interesting to consider the issues and provisions given most attention. Consider the investor-state arbitration clause. Given the truly reciprocal nature of the negotiations, with investment protection sought by both sides, ${ }^{94}$ it would almost certainly have resulted in investor-state claims against both European and Arab States. Dispute settlement under the

\footnotetext{
${ }^{87}$ Watson (FCO) to Lord Bridges (FCO), 15.7.1981; FCO 69-646.

${ }^{88}$ Financial Cooperation Working Committee, Coreu note, CPE/BIL/ETR 501, 1981; T450/72.

${ }^{89}$ Denza (FCO) to P Walker (Treasury), 28.10.1985; FCO 98-2270.

${ }^{90}$ E Graham, Fighting the Wrong Enemy: Antiglobal Activists and Multinational Enterprises ( Peterson Institute for International Economics, 2000), ch. 2.

${ }^{91}$ L Poulsen, Bounded Rationality and Economic Diplomacy: The Politics of Investment Treaties in Developing Countries. Cambridge University Press, 2015.

92 Johnson (CBI) to Denza (FCO), 1.12.1976 FCO 98-216. The UNICE proposal was blocked by Belgian and German representatives, because of the politically sensitive nature of discussions, and the UK had no strong views on the matter. It almost never consulted business regarding particular negotiations; Thomas (FCO) to Sinclair (FCO), 2.12.1976; FCO 98-216. The only other occasions when actual firms - or business institutions - are mentioned in the thousands of pages of UK files are (i) a brief exchange where the Chairman of the CBI's Overseas Investment Panel (a Shell consultant) was asked to comment on the conflicting positions on exchange controls, and (ii) a letter from Shell to the FCO saying that the Euro-Arab draft appeared superior to the Code of Conduct of Transnational Corporations discussed in the United Nations Centre on Transnational Corporations; Gowlland (FCO) to McLean (FCO) and Evans (FCO), 23.11.1981; FCO 69-650; Blair (Shell) to Gowlland (FCO), 26.10.1981; FCO 69/950.

${ }^{93}$ Ibid., 49-50.

94 The Arabs were delighted when the Europeans proposed that strong protection should apply in case of divergence between the Convention and BITs; Financial Cooperation Working Committee, Coreu note, CPE/BIL/ETR 501, 1981; T450/72.
} 
ICSID Convention had barely begun at the time, of course, but it is still noteworthy just how little the investor-state arbitration provision featured in negotiations. When European parties discussed possible costs and benefits of the Convention, one does not find reference to arguments about the need to 'de-politicize' investment disputes, for instance, or discussions about the risks of offering broad and binding consent to international investor-state arbitration even in disputes involving sovereign investors. While today international arbitration has proved the most important component of the investment treaty regime, early negotiators saw the treaties mainly as constraints on government behaviour and guidance for diplomatic resolution of investment disputes. ${ }^{95}$ There was also little attention to provisions which have later proved crucial in investor-state arbitration; most notably those on fair and equitable treatment and indirect expropriation. By contrast, considerable effort was spent on concerns about exchange control, which were led by the UK Treasury even though the UK had actually abandoned exchange controls in 1979. Negotiators could hardly have predicted the far-reaching interpretations by arbitrators of vague provisions such as fair and equitable treatment, but the Euro-Arab negotiations do illustrate the gap between the focus of investment law in the 1970s and 1980s and that of recent decades. ${ }^{96}$ A notable exception is sovereign investment, which was - not surprisingly - crucial. Western negotiators had to strike a balance between welcoming sovereign investment, as an important source of finance, while also ensuring a level playing field between government-owned and private investors. What sometimes seems a cutting-edge issue in the modern investment treaty regime ${ }^{97}$ was at the centre of the Euro-Arab negotiations during the 1970s and 1980s.

\section{CONCLUSION}

The Euro-Arab Dialogue produced an almost complete draft of what would have been the first mega-regional investment treaty. It would have remained one of the most important investment treaties to this day. The treaty could also have had broader political implications. As with modern mega-regionals, the negotiations were never just about investment protection but were part of a broader geo-political attempt by both sides to address deeper socio-economic and diplomatic challenges. While few investors showed interest in the talks, the broader political objectives were clear. In contrast to recent years, however, where investment protection talks have complicated mega-regional negotiations, the draft Euro-Arab Investment Convention was one of the few tangible measures of progress from the Dialogue. Like most BITs negotiated at the time, the negotiations attracted little public attention or public scrutiny, but its conclusion could have provided a small but significant platform for further inter-regional cooperation. ${ }^{98}$

The treaty could also have had an impact on investment policies within the two regions. The European team was not led by the European Commission, in view of the lack of exclusive EEC competence, but they were a sustained effort among European Community members to negotiate a joint investment protection treaty. This experience was carried over to the separate negotiations for a new Lome (and later Cotonou) Convention with provisions which did come

\footnotetext{
${ }^{95}$ See generally; L Poulsen, 'Beyond credible commitments: (Investment) treaties as focal points.' International Studies Quarterly forth. 2019.

${ }^{96}$ Hepburn et al., supra note 8.

${ }^{97}$ M Feldman, 'State-Owned Enterprises as Claimants in International Investment Arbitration,' ICSID Review 31(1) 2016.

98 There have been recent attempts to restore closer inter-regional cooperation - in particular at a summit in SharmEl-Sheikh, Egypt, in February 2019 - but the emphasis has been on migration, climate change and political and security issues rather than on investment protection: Council document at http://www.consilium.europa.eu/meetings/international-summit/2019/02/24-25
} 
into effect. ${ }^{99}$ Had the Euro-Arab agreement been finalized, it is likely that it would have prompted further European initiatives on international investment protection earlier than in fact happened. ${ }^{100}$ Whatever the 'alternative histories' of the investment regime had the agreement been finalized, this review has shown the potential importance of a major by some of the largest capital-exporting states in the world and which at the time seemed to be within a hair's breadth of completion. Whether the Arabs would have concluded the Convention without some grand concession from Europe is unclear, but the decade-long negotiations could very well have helped greater alignment on drafting of investment treaties across and within the two regions.

In retrospect, one of the most interesting aspects of the negotiations was the initial discussion between European and Arab states on their objective. Cooperation on investment insurance was at first a major objective for the Arabs, and it is worth recalling that at the time investment insurance was seen not just as a complement but also a possible substitute for investment protection treaties and investor-state arbitration. ${ }^{101}$ And the Arabs initially sought to include protection against monetary risks such as currency fluctuation, which the Europeans did not see as controllable by treaty rules. The foundational nature of these early discussions is important. Observers of the investment treaty regime often see current arrangements as the result of a linear and inevitable historical development, but this is misguided. The regime has been shaped by choices made under uncertainty and where alternative institutions and treaty designs were possible. Current controversies over the direction of the investment treaty regime have today re-opened some of these foundational questions - 'Why investment treaties?' 'What are investment treaties for?' - that were prominent at the time of the Euro-Arab talks.

\footnotetext{
99 This included binding obligations to accord fair and equitable treatment to foreign investment, to encourage and create favourable conditions conducive to participation by foreign investors, support conclusion of further BITs and limit the possibility of discriminatory provisions being offered by States which had already concluded such agreements. Article 243 of the Lomé II Convention (Cmnd). 9511) and the Joint Declaration in an Annex to the Convention.

${ }^{100}$ In the years following 1990 many agreements were concluded between Arab States - including Libya and Syria. For example, Algeria-Syria (1997), Egypt-Jordan (1996), Egypt-Syria (1997), Jordan-Tunisia (1995), Jordan-Yemen (1996), Lebanon-Morocco (1997), Lebanon-Syria (1997), Libya-Syria (1993), Morocco-Tunisia (1994), Oman-Tunisia (1991), Syria-United Arab Emirates (1997), Syria-Yemen (1996), Tunisia-United Arab Emirates (1996) - see International Investment Agreements Navigator (UNCTAD) Investment Policy Hub).

${ }^{101}$ St John, n. 8, ch. 3.
} 


\section{Annex:}

\section{Draft Convention Between Member States of the European Communities and Member States of the Arab League for the Reciprocal Promotion and Protection of Investments, $11^{\text {th }}$ September 1985}

\section{DRAFT CONVENTION}

Between Member States of the European Communities and Member States of the Arab League for the Reciprocal Promotion and Protection of Investments.

The States signatory hereto, being Members of the European Communities on the one hand or of the Arab League on the other hand;

Having discussed within the framework of the Euro-Arab Dialogue the reciprocal promotion and protection of their investments in each others' territories;

Desiring to create favourable conditions for greater economic co-operation between them and in particular for investments from the European Community in the Arab world and from the Arab League in the European Community;

Recognising that the reciprocal encouragement and promotion and protection under international agreement of such investments will be conducive to the stimulation of business initiative and will increase prosperity in Europe and in the Arab world;

ARTICLE 1

Definitions

For the purposes of this Convention:

(a) "investment" means every kind of asset (including assets acquired from the sale of all or part of an investment or from the re-investment of profits or other returns from an investment) and in particular, but not exclusively, includes:

(i) movable property including monetary assets, immovable property and any other property rights such as mortgages, liens or pledges, claims to money or to performance having economic value associated with an investment;

(ii) shares, stock, loans and debentures of companies wherever incorporated or interests in the property of such companies;

(iii) stocks, bonds and other securities by governments, public authorities, or international organisations;

(iv) intellectual property rights and goodwill;

(v) industrial and business concessions conferred by law or under contract (including rights to participate in industrial or business joint ventures or enterprises based on natural resources). The term "investment" covers all investments made in accordance with domestic laws or regulations or special agreements whether made before or after the entry into force of this Convention in respect of any Contracting Party;

(b) "returns" means all amounts yielded by an investment or resulting from investment activity and in particular, though not exclusively, includes:

(i) profit;

(ii) interest;

(iii) capital gains;

(iv) dividends;

(v) royalties or fees; 
(vi) proceeds of the leasing or hire of all or part of an investment.

(c) "companies" means companies, corporations, firms or associations;

(d) "investors" means in respect of each Contracting Party:

(i) such physical persons as in accordance with the relevant law are its nationals;

(ii) such companies as in accordance with the relevant law in force in any part of its territory are its nationals either by virtue of incorporation or constitution in its territory of by virtue of having their principal place of business in its territory, or which may otherwise enjoy its diplomatic protection in accordance with international law. [European proposal: but excluding in any case companies which have no genuine link with the economy of a Contracting Party.] [Arab proposal: Each Contracting Party may reserve the right to deny to a company of any other Contracting Party the advantages of this Convention if nationals of any third State control such company.]

(iii) governments, institutions and organisations constituted under the law in force in any part of its territory.

(e) "Convention area" means in respect of each Contracting Party the territory under its sovereignty, and the sea and submarine areas over which that Contracting Party exercises, in conformity with international law, sovereignty, sovereign rights or jurisdiction.

\section{ARTICLE 2}

\section{Government Investment}

Each Contracting Party hereby guarantees that investments and returns of any other Contracting Party (including its Central Bank) in its Convention area shall, insofar as this is in accordance with international law, have full and complete immunity from any measure, direct or indirect, which might in any way restrict or impair the ownership, control, enjoyment, disposal or transfer of such investments and returns.

\section{ARTICLE 3}

\section{Promotion and Protection of Investment}

(1) Each Contracting Party shall encourage and create as far as possible stable, favourable and clear conditions for investors of the other Contracting Parties to invest in its Convention area. Subject to its right to exercise powers conferred by its law or regulations, and consistently with its national economic policy, each Contracting Party shall admit such investment.

(2) Investments and returns of investors of any Contracting Party shall at all times be accorded fair and equitable treatment and shall enjoy full protection and security in the Convention area of any other Contracting Party. Each Contracting Party shall ensure that the management, maintenance, use, enjoyment or disposal in its Convention area of investments and returns of investors of any other Contracting Party is not in any way impaired by unjustifiable or discriminatory measures.

\section{ARTICLE 4}

\section{$\underline{\text { Most-favoured-nation and National Treatment Provisions }}$}

(1) No Contracting Party shall in its convention area subject investments (once admitted) or returns of investors of any other Contracting Party to treatment less favourable than that which it accords in the same circumstances to investments or returns of its own investors or to investments of any third State (whichever of these standards is the more favourable from the point of view of the investor).

(2) No Contracting Party shall in its Convention area subject investors of any other contracting Party, as regards their management, maintenance, use, enjoyment or disposal of their investment or returns, to treatment less favourable than that which it accords in the same circumstances to its own investors or to 
investors of any third State (whichever of these standards is the more favourable from the point of view of the investor).

(3) The provisions in paragraphs (1) and (2) of this Article shall not however oblige any Contracting Party to extend to the investors of any other contracting Party the benefit of any treatment, preference or privilege which may be extended by the former Contracting Party by virtue of:

(a) the formation or extension of a customs union or a free trade area or a common external tariff area or a monetary union or common exchange control area; or

(b) the adoption of an agreement designed to lead to the formation of such a union or area within a reasonable length of time; or

(c) any multilateral agreement adopted within the framework of a regional economic organisation.

(4) Each Contracting Party retains the right not to apply the provisions of paragraphs 1 and (2) of this Article insofar as they relate to the grant of national treatment to:

(a) ownership of real property when such ownership is restricted by national law to its own investors; or

(b) specified investment incentives in certain sectors offered by national law to its investors when development considerations are of overriding national importance.

\section{ARTICLE 5}

\section{Expropriation}

(1) Investments or returns of investors of any Contracting Party shall not be nationalised, expropriated or subjected to measures having effect equivalent to nationalisation or expropriation (hereinafter referred to as "expropriation") in the Convention area of any other contracting Party except for a public purpose, on a basis of non-discrimination and against prompt, adequate and effective compensation. Such compensation shall amount to the market value of the investment or return expropriated immediately before the expropriation or impending expropriation became public knowledge, or in the absence of a determinable market value, the actual loss sustained, shall be made without undue delay and shall include interest, shall be effectively realisable and be freely transferable. Interest shall be paid at the prevailing rate in the international money market (such as the London Inter-Bank Offer Rate) where such a market exists and otherwise at the prevailing rate in the domestic market. There shall be legal provision giving the investor concerned a right to prompt review of the legality of the measure taken against the investment or return and of their valuation in accordance with the principles set out in this paragraph by due process and by an independent authority (whether judicial or administrative) of the Contracting Party making the expropriation.

(2) Where a Contracting Party expropriates the assets of a company which is incorporated or constituted under the law in force in any part of its own territory, and in which investors of any other contracting Party own shares or debentures, it shall ensure that the provisions of paragraph (1) of this article are applied to the extent necessary to guarantee prompt, adequate and effective compensation in respect of their investment to the owners of these shares or debentures.

[Arab proposal: (3) Investments or returns of investors of any Contracting Party shall not be subject in the territory of any other Contracting Party to freezing or any other measure having effect equivalent to freezing, unless it is taken in application of judicial measures.]

\section{ARTICLE 6}

Compensation for losses 
(1) Investors of one Contracting Party whose investments in the Convention area of any other contracting Party suffer losses owing to war or other armed conflict, revolution, a state of national emergency, revolt, insurrection or riot in the Convention area of the latter Contracting Party, shall be accorded by the latter Contracting Party treatment, as regards restitution, indemnification, compensation or other settlement, no less favourable than that which the latter Contracting Party accords to its own investors or to investors of any third State (whichever of these standards is the more favourable from the point of view of the investor).

(2) Without prejudice to paragraph (1) of this Article investors of any Contracting Party who in any of the situations referred to in paragraph (1) suffer losses in the Convention area of any other contracting Party resulting from:

(a) requisitioning of their property by its forces or authorities;

(b) destruction of their property by its forces or authorities which was not caused in combat action and was not required by the necessity of the situation;

shall in any event be accorded restitution or adequate compensation. Payments resulting from any provision in this Article shall be freely transferable.

\section{ARTICLE 7}

\section{$\underline{\text { Repatriation of Investment and Returns }}$}

(1) Each Contracting Party shall guarantee in respect of investments of investors of any other contracting Party the unrestricted transfer of their investments and returns. Transfers of currency shall be effected without delay in the convertible currency in which the capital was originally invested unless any other convertible currency is agreed by the investor and the Contracting Party concerned. Unless otherwise agreed transfers shall be made at the rate of exchange applicable on the date of transfer.

(2) Each Contracting Party retains the right not to apply the provisions of paragraph (1) of this Article if sudden or unusual capital movements or current payments result in difficulties or seriously threaten to result in difficulties as regards its balance of payments. The exercise of this right shall be subject to the following conditions:

(i) it may be used for a limited period only, and only to the extent necessary;

(ii) it shall be exercised on a basis of non-discrimination; and

(iii) at the request of any contracting Party concerned there shall be prompt and adequate consultations on the measures taken.

Such powers shall not however be used to impede the transfer of returns, and as regards the proceeds of the sale or the liquidation of the investment the actual transfer may be spread over as few years as possible, but not more than five years.

(3) Each Contracting Party shall allow the free transfer of at least 50\% of the amount of salaries, wages and other emoluments received in its Convention area by nationals of any other contracting Party, working on an investment project covered by this convention.

\section{ARTICLE 8}

\section{Taxation}

(1) Article 4 of this Convention does not apply to any taxation measure. The Contracting Parties agree that in some circumstances taxation policies or laws may constitute an obstacle to investment. Contracting Parties shall use their best efforts to overcome any such obstacle, where appropriate by further special bilateral or multilateral agreements in regard to taxation.

\section{ARTICLE 9}




\section{$\underline{\text { Subrogation }}$}

If any contracting Party (or its designated Agency) makes payment under an indemnity it has given, or if rights or securities are transferred to such Contracting Party (or its designated Agency) under a legal system of guarantee against risks in respect of an investment or any part thereof in the Convention area of any other contracting Party, the latter Contracting Party shall recognise:

(a) the assignment of any right or claim from the party indemnified to the former contracting Party (or its designated Agency), and

(b) that the former contracting Party (or its designated Agency) is entitled by virtue of subrogation to exercise the rights and enforce the claims of such a party.

The former Contracting Party (or its designated Agency) shall accordingly if it so desires be entitled to assert any such right or claim to the same extent as its predecessor in title either before a court or tribunal in the territory of the latter Contracting Party or in any other circumstances. If the former Contracting Party acquires amounts in the lawful currency of the other contracting Party or credits thereof by assignment under the terms of an indemnity, the former Contracting Party shall be accorded in respect thereof treatment not less favourable than that accorded to the funds of investors of the latter contracting Party or of any third state deriving from investment activities similar to those in which the party indemnified was engaged.

\section{ARTICLE 10}

\section{$\underline{\text { Settlement of Disputes between an Investor and a Host State }}$}

(1) Disputes between an investor of one Contracting Party and any other Contracting Party concerning an obligation of the latter under this Convention in relation to an investment of the former shall in the first instance be dealt with by pursuit of local remedies unless some other method, including arbitration, is agreed between the investor and the Contracting Party. Where however no settlement has been reached after a period of six months from written notification of a claim any such dispute shall be submitted to international arbitration if either party to the dispute so wishes.

(2) Where the dispute is referred to international arbitration, the investor and the Contracting Party concerned in the dispute may agree to refer the dispute either to:

(a) the International Centre for the settlement of Investment Disputes (having regard to the provisions, where applicable, of the Convention on the settlement of Investment Disputes between States and Nationals of other States, opened for signature at Washington on 18 March 1965 and the Additional Facility for the Administration of Conciliation, Arbitration and Fact-Finding Proceedings); or

(b) the Court of Arbitration of the International Chamber of Commerce; or

(c) an international arbitrator or ad hoc arbitration tribunal to be appointed by a special agreement or established under the Arbitration Rules of the United Nations Commission on International Trade Law.

If after a further period of three months from written notification of the claim there is no agreement to any of the alternative procedures described above, the parties to the dispute shall be bound to submit it to arbitration under the Arbitration Rules of the United Nations Commission on International Trade Law as then in force. The Parties to the dispute may agree in writing to modify these Rules.

(3) This Article applies only to disputes arising after the entry into force of this convention. Any dispute arising before the entry into force of this convention may however, by agreement between the parties to the dispute, be submitted to arbitration in accordance with the above provisions.

\section{ARTICLE 11}

Disputes between the Contracting Parties 
(1) Disputes between the contracting Parties concerning the interpretation or application of this convention should, if possible, be settled through diplomatic channels.

(2) If a dispute between two or more contracting Parties cannot thus be settled, it shall upon the request of any Party to the dispute be submitted to an arbitral tribunal.

(3) Such an arbitral tribunal shall be constituted for each individual case in the following way. Within two months of the receipt of the request for arbitration, each Party to the dispute shall appoint one member of the tribunal. Where there is an imbalance between the number of European and the number of Arab parties to the dispute, the group with the smaller number of parties may appoint additional members to the extent necessary to reach equality of numbers between the two sides. Those members shall then select a national of a third State (or two such nationals if this is necessary to produce an uneven number). This additional Member, or one of these additional Members, on approval by the Parties to the dispute shall be appointed Chairman of the tribunal. The Chairman shall be appointed within two months from the date of appointment of the other members.

(4) If within the periods specified in paragraph (3) of this Article the necessary appointments have not been made, any party to the dispute may, in the absence of any other agreement, invite the President of the Court of Arbitration of the International Chambers of Commerce to make any necessary appointments. If the President of the Court is a national of any Party to this dispute or if he is otherwise prevented from discharging the said function, the most senior Vice-President or if he too is prevented from discharging the said function, the Member of the Court next in seniority who is not a national of any party to the dispute shall be invited to make the necessary appointments.

(5) The arbitral tribunal shall reach its decision by a majority of votes. Such decision shall be binding on all parties. Each contracting Party shall bear the cost of its own member of the tribunal and of its representation in the arbitral proceedings: the cost of the chairman and the remaining costs shall be borne in equal parts by the parties to the dispute. The tribunal may, however, in its decision direct that a higher proportion of costs shall be borne by one of the parties, and this award shall be binding on all parties. The tribunal shall determine its own procedure.

\section{ARTICLE 12}

\section{$\underline{\text { Relationship to other Agreements }}$}

(1) The provisions of this convention shall not as between Member States of the European Economic Community or as between Member States of the Arab League create rights or obligations, or vary their mutual rights or obligations under other international agreements. Each contracting Party shall however observe the obligations it may have entered into with regard to investments and returns of investors of any other contracting Party.

(2) Subject to paragraph (1) of this Article, where two or more Contracting Parties to this convention have entered into a prior international agreement, or enter into a subsequent international agreement, whose terms in either case conflict with those of this Convention, the more favourable of the conflicting provisions from the point of view of the investor shall in all circumstances prevail. The Contracting Parties to this convention may enter into subsequent international agreements, whether bilateral or multilateral, confirming, supplementing, expanding or applying the provisions of this convention.

\section{ARTICLE 13}

\section{$\underline{\text { Reservations }}$}

[Arab Proposal: No reservations shall be permitted to this convention.]

[European Proposal: Reservations may be made only to Article 6 of this Convention.]

\section{ARTICLE 14}

Signature and Ratification, Approval or Accession 
(1) This Convention shall be open for signature until by States Members of the European Communities and States Members of the Arab League.

(2) This convention shall be subject to ratification or approval. Instruments of ratification or approval shall be deposited with the Council of the European Communities and with the Secretariat of the Arab League.

(3) After its entry into force, this convention shall be open to accession by the States referred to in paragraph (1) of this Article.

(4) Instruments of accession shall be deposited with the Council of the European Communities and with the Secretariat of the Arab League.

[European Proposal: (5) This convention shall also be open for signature, ratification, approval or accession in accordance with the procedure prescribed in this Article by an international organisation, subject to the following conditions:

(a) that it is an inter-governmental organisation constituted either exclusively by States Members of the European Communities on the one hand or exclusively by States Members of the Arab League on the other hand;

(b) that it owns investments within the Convention area of a Contracting Party being in the case of a European international organisation a Member State of the Arab League and being in the case of an Arab international organisation a Member state of the European Communities; and

(c) that it is an organisation which has competence to protect its own investments, including the competence to enter into treaties in order to protect such investments.

An international organisation which becomes a Contracting Party to this Convention shall exercise rights and perform obligations under this Convention solely in order to protect its investments and returns and to the extent of its competence.]

\section{ARTICLE 15}

\section{Entry into Force}

(1) This Convention shall enter into force as soon as two States Members of the European Communities and two States Members of the Arab League have deposited instruments of ratification or approval.

(2) For States whose instruments of ratification, approval or accession are deposited subsequent to the entry into force of this convention, it shall enter into force on the date of the deposit of their instruments of ratification, approval or accession.

\section{ARTICLE 16}

\section{Duration of the Convention}

The present Convention shall be of unlimited duration. Any contracting Party to which the Convention has applied for ten years may give twelve months' prior notice of withdrawal from the Convention to the Council of the European Communities or the Secretariat of the Arab League, and on the expiry of the twelve months' notice shall (unless the notice has been withdrawn) cease to be a Contracting Party to the Convention. In respect of investments made while such a State was a Contracting Party to this Convention, it shall however continue for a period of twenty years after withdrawal to be entitled to the rights and subject to the obligations of the Convention, but without prejudice to the application, in other circumstances and thereafter, of the rules of international law.

ARTICLE 17

Notifications 
(1) The Council of the European Communities and the Secretariat of the Arab League shall promptly inform each other and all signatory and acceding States of the date of each signature, the date of deposit of each instrument of ratification, approval or accession, the date of entry into force of this convention, and of any notice of proposed withdrawal.

(2) This Convention shall be registered by the Council of the European Communities pursuant to Article 102 of the Charter of the United Nations.

\section{ARTICLE 18}

\section{Languages of the Convention}

This convention, the English, French and Arabic texts of which are equally authoritative, shall be deposited in the archives of the Council of the European Communities and of the Secretariat of the Arab League. Duly certified copies of this convention shall be transmitted to the Governments of the signatory and acceding States.

In witness whereof the undersigned, duly authorised thereto, have signed this convention.

Done in duplicate at on

equivalent to [Hadji date], one copy to be retained by the Council of the European Communities and one copy by the Secretariat of the Arab League. 